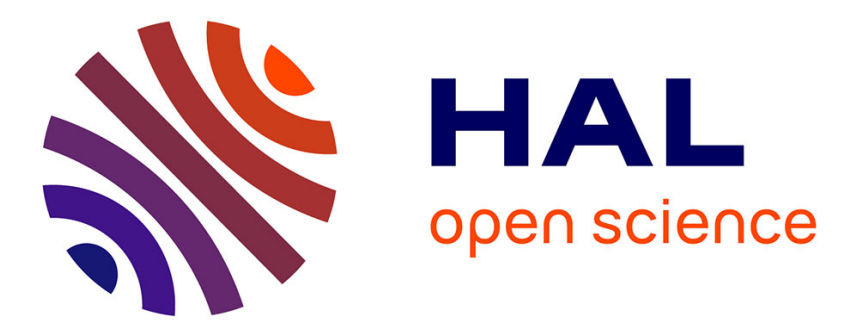

\title{
Short-term profiles of plasma gonadotropin and $17 \alpha$-hydroxy, $20 \beta$-dihydroprogesterone levels in the female rainbow trout at the periovulatory period
} Yonathan Zohar, Bernard Breton, Alexis Fostier

\section{- To cite this version:}

Yonathan Zohar, Bernard Breton, Alexis Fostier. Short-term profiles of plasma gonadotropin and $17 \alpha$-hydroxy, 20 $\beta$-dihydroprogesterone levels in the female rainbow trout at the periovulatory period. General and Comparative Endocrinology, 1986, 64 (2), pp.189-198. 10.1016/0016-6480(86)90003-1 . hal-02728246

\section{HAL Id: hal-02728246 \\ https://hal.inrae.fr/hal-02728246}

Submitted on 2 Jun 2020

HAL is a multi-disciplinary open access archive for the deposit and dissemination of scientific research documents, whether they are published or not. The documents may come from teaching and research institutions in France or abroad, or from public or private research centers.
L'archive ouverte pluridisciplinaire HAL, est destinée au dépôt et à la diffusion de documents scientifiques de niveau recherche, publiés ou non, émanant des établissements d'enseignement et de recherche français ou étrangers, des laboratoires publics ou privés.

\section{다(1)(2)}

Distributed under a Creative Commons Attribution - ShareAlikel 4.0 International 


\title{
Short-Term Profiles of Plasma Gonadotropin and $17 \alpha$-Hydroxy, $20 \beta$-dihydroprogesterone Levels in the Female Rainbow Trout at the Periovulatory Period
}

\author{
Y. ZOHAR, ${ }^{1}$ B. Breton, AND A. FostiER \\ Laboratoire de Physiologie de Poissons, INRA, Campus de Beaulieu, 35042 Rennes, France
}

Accepted May 12, 1986

\begin{abstract}
Individual free-swimming female rainbow trout in which oocytes underwent final stages of germinal vesicle migration, maturation, or ovulation were bled via a dorsal-aortic catheter at frequencies of once every 1,3 , or $4 \mathrm{hr}$ over periods of 9 to $36 \mathrm{hr}$. Gonadotropin $(\mathrm{GtH})$

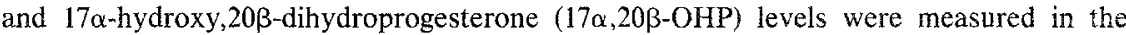
plasma samples. GtH levels were elevated and showed wide and progressive daily variations. A high degree of synchronization appeared among the GHH profles of individual fish. Two distinct daily GtH surges were observed, one at early photophase and the other during the mid-scotophase. The onset of the GtH increases was closely related to the beginning of the photophase and the scotophase, respectively. In females undergoing oocyte maturation or in ovulated females, $17 \alpha, 20 \beta$-OHP levels were increasing or high, showing progressive daily fluctuations that were either synchronized with the GtH changes or somewhat phaseshifted in relation to them. These data are discussed in relation to the seasonal changes in the short-term profiles of reproductive hormones in the trout. 1986 Academic Press, Inc.
\end{abstract}

In teleosts, oocyte maturation and ovulation are accompanied by a significant increase in plasma gonadotropin $(\mathrm{GtH})$ levels (salmonids: Crim et al., 1975; Fostier et al., 1978, 1981a; Fostier and Jalabert, 1986; Breton et al., 1983; Scott et al., 1983; Scott and Sumpter, 1983; Bromage et al., 1982; Whitehead et al., 1983; Young et al., 1983; cyprinids: Breton et al., 1972; Stacey et al., 1979a; Breton et al., 1980; cypriniformes: Stacey et al., 1984). In various salmonid species, ovulation is preceded by a continuous decrease, first in estradiol- $17 \beta$ $\left(E_{2} 17 \beta\right)$ and then in testosterone levels, and by a drastic increase in $17 \alpha$-hydroxy, $20 \beta$ dihydroprogesterone $(17 \alpha, 20 \beta-O H P)$, the most probable maturation-inducing steroid in salmonidae (rainbow trout: Fostier et al., 1978, 1981a; Fostier and Jalabert, 1982,

\footnotetext{
${ }^{1}$ Present address for reprint requests: National Center for Mariculture, Israel Oceanographic and Limnological Research Institute, P.O. Box 1212, 88112 Elat, Israel.
}

1986; Scott and Baynes, 1982; Scott et al., 1982, 1983; amago salmon: Young et al., 1983; Atlantic salmon and coho salmon: Wright and Hunt, 1982; masu salmon: Yamauchi et al., 1984). The same general pattern also occurs in the white sucker (cypriniformes: Scott et al., 1984). In the goldfish (Cyprinidae), $E_{2} 17 \beta$ levels stay high during maturation and ovulation while there might be a short and relatively shallow peak of $17 \alpha, 20 \beta-O H P$ preceding oocyte maturation (Stacey et al., 1983; Kagawa et al., 1983; Peter et al., 1984).

Although a great deal of attention has been drawn to hormonal changes at the periovulatory period in teleosts, only a few studies have explored short-term (circadian and ultradian) fluctuations of the hormones. Pan et al. (1980) recorded daily variations in plasma $\mathrm{GtH}$ levels in three carp species at their spawning time. In the catfish, Lamba et al. (1983) demonstrated daily changes in plasma levels of cortisol, testosterone, $E_{2} 17 \beta$, and estrone during the 
"spawning period." In the goldfish, Hontela and Peter (1978) found more pronounced daily variations in plasma GtH levels in "mature" fish, as compared to fish at earlier stages of ovarian developent. In the same species, Stacey et al. (1979a) demonstrated a preovulatory surge of $\mathrm{GtH}$, the duration of which was approximately $24 \mathrm{hr}$. Our previous paper (Zohar $e t$ al., 1986) demonstrated, in the female rainbow trout, that important changes occur in the short-term profiles of blood $\mathrm{GtH}$ and $\mathrm{E}_{2} 17 \beta$ levels from early ovarian recrudescence and throughout vitellogenesis. The present paper describes the short-term GtH and $17 \alpha, 20 \beta$-OHP profiles in individual rainbow trout females at the periovulatory period.

\section{MATERIALS AND METHODS}

\section{(a) Experimental Conditions}

The experiments were carried out from December through January each year over a 3-year period. Female trout aged 3 to 4 years and weighing 1.5 to $3 \mathrm{~kg}$ were used. All of them had reached sexual maturity at least once before. Animal stocking conditions and dorsal aorta catheterization procedures have been described in the previous paper (Zohar et al., 1986). After catheterization, fish were allowed to recover for at least 3 days before they were bled. Only fish which had resumed normal feeding behavior after surgery were selected for experimentation. Individual freeswimming catheterized trout were bled repeatedly via the catheter at frequencies of once every 1,3 , or $4 \mathrm{hr}$ over periods of 9 to $36 \mathrm{hr}$. Blood sampling was done according to Zohar et al. (1986). Blood samples were centrifuged $\left(15 \mathrm{~min}\right.$ at $5000 \mathrm{rpm}$ and at $\left.4^{\circ}\right)$, and the plasma was stored at $-30^{\circ}$ until further analysis.

\section{(b) Determination of Ovarian \\ Developmental Stages}

At the beginning and the end of each experiment, a few oocytes were extracted from the ovaries by abdominal pressure (stripping). The stage of oocyte development was determined under a binocular microscope according to Jalabert et al. (1976):

Maturation. The meiotic maturation is preceded by the migration of the germinal vesicle (GV) toward the animal pole of the oocyte (GVM). The GV becomes more visible as it approaches the oocyte periphery. The visible phenomena of the maturation start with the progressive fusion of the vitellin spheres and the peripheral migration of the lipid globules (cytoplasmatic maturation), and terminate with germinal vesicle breakdown (GVBD).

Ovulation. The oocytes, expulsed from their follicular envelopes, are found free in the central cavity.

\section{(c) Hormonal Measurements}

The procedures of the radioimmunoassay (RIA) for the $\mathrm{GtH}$ as well as the RIA precision have been given in detail by Zohar et al. (1986).

The RIA of $17 \alpha, 20 \beta-O H P$ was carried out according to Fostier et al. (1981b), using the same antibody. The intraassay variability was $5.9 \%$ for hormone levels of $9-10 \mathrm{ng} / \mathrm{ml}$ and $7.4 \%$ for hormone levels between 65 and $80 \mathrm{ng} / \mathrm{ml}$.

\section{(d) Analytical Methods}

The mathematical and statistical analysis of our data has been described in detail in the previous paper (Zohar et al., 1986). In the present study, we dealt only with regular fluctuating hormonal profiles.

\section{RESULTS}

In most females sampled, oocytes either were in the final stages of germinal vesicle migration or were undergoing maturation. In some cases, ovulation occurred within the 72-hr recovery period between catheterization and successive bleeding (OV in figures).

The overall mean GtH level in the periovulatory period $(12.9 \pm 2.8 \mathrm{ng} / \mathrm{ml}$ for all sampling times of all females) was significantly higher (Student $t$ test, $P<0.01$ ) than the mean basal GtH level recorded at early ovarian recrudescence $(2.3 \pm 0.6 \mathrm{ng} / \mathrm{ml})$, or at early $(1.8 \pm 0.4 \mathrm{ng} / \mathrm{ml})$ or advanced $(2.4 \pm 0.6 \mathrm{ng} / \mathrm{ml})$ exogenous vitellogenesis (Zohar et al., 1986). In 21 of 25 fish sampled during the periovulatory period, $\mathrm{GtH}$ profiles fluctuated significantly. The nature of the changes in the GtH levels during this period was different from that found in earlier ovarian developmental stages (Zohar et al., 1986). Episodic changes in GtH levels no longer occurred, and those levels instead showed wide, progressive, and continuous daily fluctuations. A consistent daily cycle was observed in all sampled fish, independent of the sampling frequency (Figs. 
1-5). There was a synchronization among individual profiles.

Figure 1 shows GtH profiles in 10 female trout sampled every hour over a period of 9 hr. Significant fluctuations in GtH levels were observed in eight of them. In all sampled females, GtH levels decreased progressively from early photophase (lights were on at $0720 \mathrm{hr}$ ) to minimal values found at the middle and the second part of the photophase, i.e., between 1100 and $1600 \mathrm{hr}$, according to the females. Gonadotropin levels increased again just before and at the heginning of the scotophase (see also Fig.
2). Bleeding fish every hour over a period of $12 \mathrm{hr}$ (Fig. 2) showed that the above-described decrease in $\mathrm{GtH}$ levels during the photophase is, in fact, the descending part of a large GtH surge associated with the onset of the photophase (highly significant in four of the females and at the limit of signification in the fifth). The increase in $\mathrm{GtH}$ levels in all fish started shortly before or at the onset of light, the maximal levels being achieved within 2 to $3 \mathrm{hr}$. As in Fig. 1, after the GtH decline, the start of a subsequent upsurge was observed (Fig. 2).

The high degree of synchronization

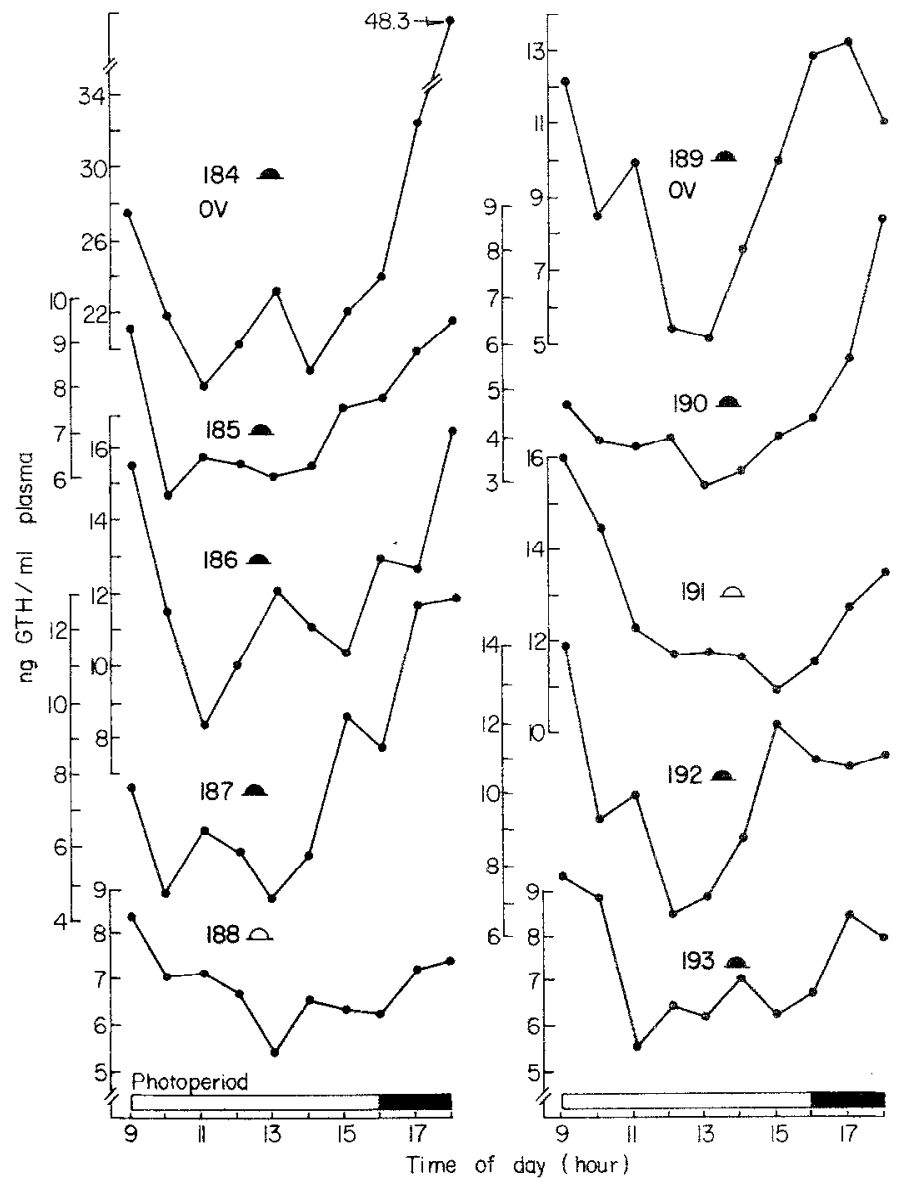

FIG. 1. Individual profiles of plasma GtH levels in female trout at the periovulatory period (December-January). Females were bled every hour over a period of $9 \mathrm{hr}$. The number of each female is indicated. The symbol OV refers to females in which ovulation occurred within the 72 -hr recovery period between catheterization and successive bleeding. The symbol means that the GtH profile fluctuated significantly, whereas the symbol $\triangle$ means that GtH fluctuations were not significant. 


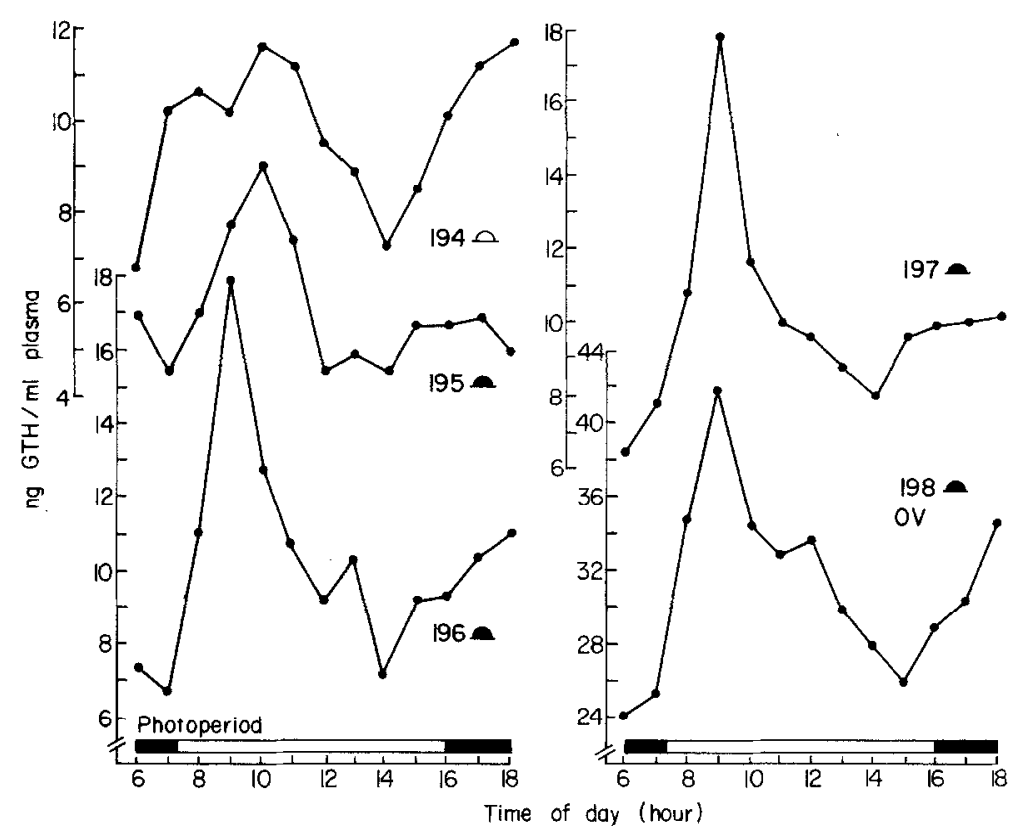

FIG. 2. Individual profiles of plasma GtH levels in female trout at the periovulatory period (December). Females were bled every hour over a period of $12 \mathrm{hr}$. For additional details, see the legend of Fig. 1.

among the individual $\mathrm{GtH}$ profiles of the fish sampled hourly (Figs. 1 and 2) can be seen in their averages as presented in Fig. 3 . These average profiles show, in a significant manner $(P<0.01)$, the GtH surge associated with "dawn" (Fig. 3b), the gradual GtH decrease starting from early morning and continuing through the major part of the photophase, and the increase which follows it toward and during early scotophase (Figs. 3a, b).

Figure 4 shows the average profile of $\mathrm{GtH}$ changes in five female trout sampled every $4 \mathrm{hr}$ over a period of $24 \mathrm{hr}$. This profile confirms the above results and shows a significant circadian cycle in plasma $\mathrm{GtH}$
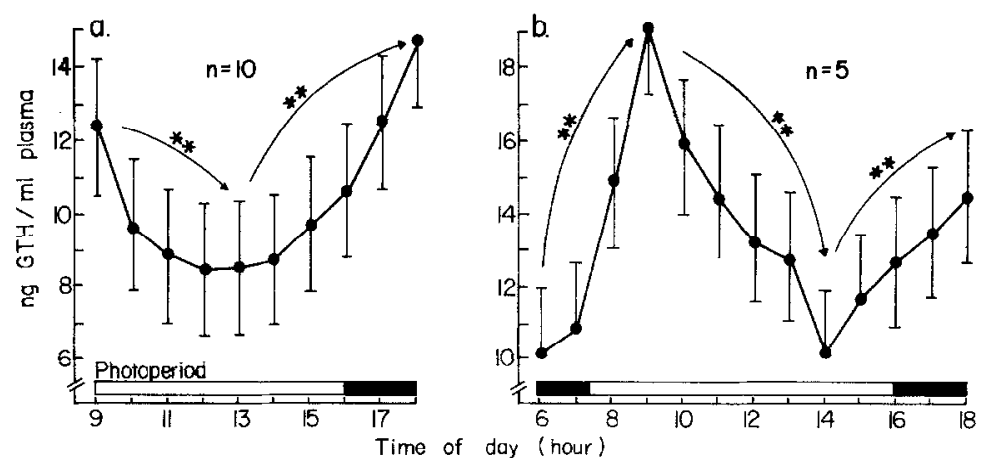

FIG. 3. Mean profiles ( $x \pm \mathrm{tSE}$ ) of plasma GtH levels in female trout at the periovulatory period (December-January). The mean profiles were established from the individual GtH profiles shown in Fig. 1 (for (a)) and Fig. 2 (for (b)). Fish were bled every hour over a period of 9 (a) or 12 (b) hr. **Significant difference at $p<0.01$. 


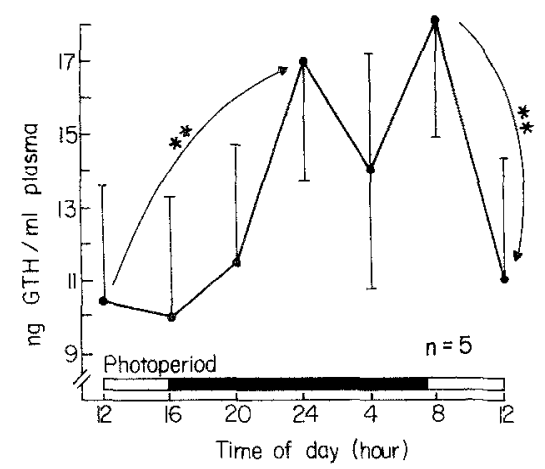

Fig. 4. Mean profile of plasma GtH levels in female trout at the periovulatory period (December). This profile was established from individual $\mathrm{GtH}$ profiles (not shown) of females which were bled every $4 \mathrm{hr}$ over a period of $24 \mathrm{hr}$. ${ }^{* *}$ Significant difference at $P<$ 0.01 .

levels. Gonadotropin levels increased significantly from early scotophase and remained elevated during the dark period. The decrease in GtH levels in the second part of the scotophase, which precedes the "dawn" GtH surge, was not significant in this case, probably due to the relatively low frequency of bleeding. Fish sampled every $3 \mathrm{hr}$ over $36 \mathrm{hr}$ also showed the same general daily pattern of GtH levels (two profiles of such fish, Nos. 206 and 207, are shown in Fig. 5). In this case, the GtH decrease at late scotophase was more evident.

Figure 5 shows the individual profiles of plasma GtH and $17 \alpha, 20 \beta$-OHP levels in seven females. Some of them were bled every hour over a period of 9 or $12 \mathrm{hr}$, and others every 3 hr over 36 hr. Female No. 199 was bled every $4 \mathrm{hr}$ over a period of 24 hr. Three of the females underwent oocyte maturation (Mat) at the end of the sampling period, whereas in the others ovulation (OV) was completed. All females showed daily fluctuations in GtH levels, similar to those described above. Plasma levels of $17 \alpha, 20 \beta-O H P$ also fluctuated significantly in all the fish (Fig. 5).These fluctuations were continuous and progressive. In one female (No. 206) showing early signs of oocyte maturation (cytoplasmatic maturation, the $\mathrm{GV}$ being still intact), $17 \alpha, 20 \beta-O H P$ levels increased sharply during the sampling period, from 20 to $220 \mathrm{ng} / \mathrm{ml}$. In two other females (Nos. 194 and 207) showing more advanced stages of oocyte maturation (GVBD), circulating 17 $\alpha, 20 \beta-O H P$ levels were high $(250-500 \mathrm{ng} / \mathrm{ml})$ and had a pattern closely parallel to that of $\mathrm{GtH}$. In the four females which eventually ovulated, the levels of $17 \alpha, 20 \beta$-OHP were either as high as or lower than those recorded in the fish which underwent oocyte maturation. In female No. 184, the plasma levels of $17 \alpha, 20 \beta-O H P$ closely paralleled those of $\mathrm{GtH}$, whereas in the other fish the $17 \alpha, 20 \beta$ OHP profiles were phase-shifted in relation to GtH.

\section{DISCUSSION}

The present study confirms the well-documented increase in plasma $\mathrm{GtH}$ levels which occurs in the female of different salmonid species at the periovulatory period. It shows, in addition, that from final stages of germinal vesicle migration there is a drastic change in the short-term profiles of plasma GtH levels. The intermittent, episodic pattern of $\mathrm{GtH}$ release, characterizing the advanced stages of vitellogenesis (Zohar et al., 1986), was no longer observed, and GtH levels instead showed continuous and gradual daily changes. Also, a high degree of synchronization was apparent among the individual $\mathrm{GtH}$ profiles. Plasma GtH levels showed two maxima, one in the early photophase and the other at the middle of the scotophase. the initiation of the increase in GtH levels coinciding closely with "dawn" and "dusk," respectively. This fact suggests a regulatory role of the photoperiod in the daily GtH fluctuations. In the goldfish, Stacey et al. (1979a, b) have demonstrated a preovulatory $\mathrm{GtH}$ surge which is synchronized with the photoperiod. Maximal $\mathrm{GtH}$ levels were reached during the 


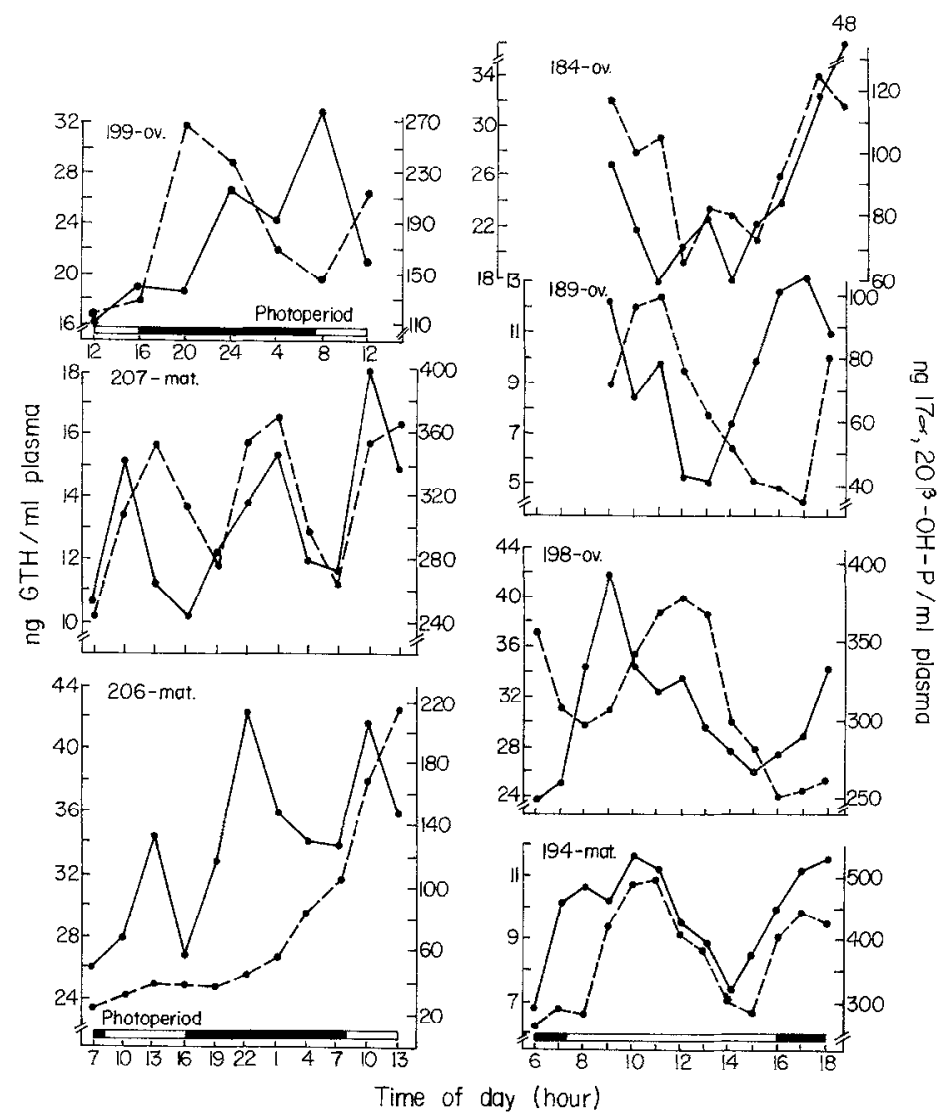

FIG. 5. Individual profiles of plasma levels of GtH (continuous lines) and 17 $\alpha, 20 \beta-O H P$ (broken lines) in female trout at the periovulatory period (December-January). Females were bled either every hour over a period of 9 or $12 \mathrm{hr}$, every $3 \mathrm{hr}$ over $36 \mathrm{hr}$, or every $4 \mathrm{hr}$ over $24 \mathrm{hr}$. For additional details, see the legend of Fig. 1.

night, and ovulation took place toward the end of the scotophase.

A circadian rhythmicity of ovulation or spawning time has been observed in several species of teleosts: Oryzias latipes (Robinson and Rugh, 1943; Egami, 1954), Rivulus marmoratus (Harrington, 1963), Trichopsis vittatus and Trichopsis pumilus (Marshall, 1967), Pagrus ehrenbergii (Stepkina, 1973), Pomatomus saltatrix (Norcross et al., 1974), Menidia audens (Hubbs, 1976), and Sparus aurata (Zohar and Gordin, 1979). In most of these cases, as well as in the goldfish (Stacey et al., $1979 \mathrm{~b}$ ), the time of ovulation or spawning seems to be dependent on photoperiod.
Thus, a daily rhythmicity of ovulation and spawning, entrained by the photoperiod, seems to be a fairly common phenomenon in fish. This rhythmicity might reflect circadian changes in the gonadotropin function, as was suggested for Orizias latipes (Iwamatsu, 1978), and observed in the goldfish (Stacey et al., 1979a) and in the rainbow trout (the present study). In the rainbow trout, we still have to establish the temporal relationships between the daily variations in circulating $\mathrm{GtH}$ and the processes of oocyte maturation and ovulation, as well as the dependence of both phenomena on photoperiod. Yet, when analyzing the two different models of the gold- 
fish and the trout, a certain analogy might be established between their $\mathrm{GtH}$ profiles throughout oocyte maturation and ovulation. In goldfish, which spawn in warm water, maturation and ovulation are rapid (24 hr or less; Jalabert et al., 1973; Sokolowska et al., 1984) and are preceded by one daily GtH surge (Stacey et al., 1979a). In trout, which spawn in cold water, maturation and ovulation take much longer ( 3 to 6 days; Jalabert, 1978; Bry, 1981). In the latter case, several successive daily $\mathrm{GtH}$ surges might constitute the gradual GtH increase accompanying oocyte maturation and ovulation. In both species, however, the gonadotropic signal related to oocyte maturation and ovulation might be composed of daily elevations of GtH, probably synchronized with the photoperiod.

As long as the first signs of oocyte maturation (cytoplasmatic maturation) were not visible, no $17 \alpha, 20 \beta-\mathrm{OHP}$ was detected in the circulation, although $\mathrm{GtH}$ levels were already elevated prior to this stage (at germinal vesicle migration). The levels of this steroid increased rapidly at the stage of cytoplasmatic maturation and before germinal vesicle breakdown. These observations are in agreement with data showing that in the female rainbow trout, the $\mathrm{GtH}$ stimulates, in vivo (Scott et al., 1982; Wright and Hunt, 1982; Fostier and Jalabert, 1986) and in vitro (Fostier et al., 1981b; Fostier and Jalabert, 1986; Zohar et al., 1982), a drastic increase in the secretion of $17 \alpha, 20 \beta-O H P$, which is followed by oocyte maturation. Once the levels of $17 \alpha, 20 \beta-O H P$ reached high values, when oocytes were more advanced in the process of maturation or were ovulated, they presented regular circadian fluctuations. These fluctuations either were closely synchronized with the GtH changes or were phase-shifted in relation to them. Such temporal relationships suggest a role of the circadian $\mathrm{GtH}$ variations, which are established first, in the regulation of the daily fluctuations of $17 \alpha, 20 \beta$-OHP. The shift between the GtH and the $17 \alpha, 20 \beta$-OHP profiles which appears after ovulation might reflect the appearance of a negative feedback exerted by $17 \alpha, 20 \beta-O H P$ on GtH sccretion (Jalabcrt et al., 1980).

In the rainbow trout, the increase in $\mathrm{GtH}$ levels prior to oocyte maturation is preceded by a progressive decline in $E_{2} 17 \beta$ (see introduction). Such a change might indicate that at the periovulatory period, the continuous rather than episodic elevated levels of $\mathrm{GtH}$ are the reflection, at the pituitary level, of the removal of a negative $\mathrm{E}_{2} 17 \beta$ feedback on $\mathrm{GtH}$ secretion (Bommelaer et al., 1981). On the other hand, the drop in $E_{2} 17 \beta$ and the following elevation in $17 \alpha, 20 \beta$-OHP levels might be the reflection of a change in the ovarian steroidom genic responsiveness to the GiH signals, which occurs at this time. In fact, in a separate study, we have shown that both short $\mathrm{GtH}$ pulses and constant elevated GtH levels stimulated $\mathrm{E}_{2} 17 \beta$ secretion from vitellogenic follicles incubated in vitro. However, continuous elevated levels of $\mathrm{GtH}$ reduced $E_{2} 17 \beta$ secretion from follicles undergoing maturation, yet at the same time were necessary to induce $17 \alpha, 20 \beta-O H P$ release (Zohar, 1982; Zohar et al., 1982). The circadian rhythm in GtH levels at the periovulatory period might be related to a parallel rhythm in the sensitivity of the ovary to $\mathrm{GtH}$. A daily cycle in the responsiveness of the ovary (indicated by its growth rate) to gonadotropin treatment has been observed in Notemigunus crysoleucas (de Vlaming and Vodicnik, 1977) and in the goldfish (Peter et al., 1982). The last study showed that under some environmental conditions, there was a synchronization between the temporal changes in ovarian sensitivity to $\mathrm{GtH}$ and the daily cycle of $\mathrm{G} t \mathrm{H}$ levels in the plasma. Moreover, it has been shown that the gonadal response to different preparations of gonadotropin, as estimated by measuring the production of steroids in Fundulus grandis (MacGregor et al., 1985) and the production of $c$-AMP in 
the Mugil cephalus (Kuo and Watanabe, 1978), fluctuated during the day.

In conclusion, this and our previous study (Zohar et al., 1986) have demonstrated that important modifications occur in the short-term profiles of plasma $\mathrm{GtH}$ and gonadal steroid levels in the female rainbow trout throughout ovarian development. At the stage of early ovarian recrudescence, short-term, high-amplitude GtH pulses occur in association with low and stable $\mathrm{E}_{2} 17 \beta$ levels. At the stage of early exogenous vitellogenesis, GtH and $\mathrm{E}_{2} 17 \beta$ levels are both low and constant. Throughout vitellogenesis, GtH pulsatility again appears accompanied by a marked increase in $E_{2} 17 \beta$ levels. Thus, at advanced stages of exogenous vitellogenesis, shortterm episodic GtH pulses of moderate amplitude are accompanied by wide and progressive daily variations of $E_{2} 17 \beta$ levels (Zohar et al., 1986). At the periovulatory period, GtH levels become continuously elevated and fluctuate in a regular circadian pattern, probably entrained by the photoperiod. Plasma levels of $17 \alpha, 20 \beta-\mathrm{OHP}$ rise rapidly just before the onset of oocyte maturation and then show wide daily fluctuations related to those of the GtH.

\section{ACKNOWLEDGMENTS}

We thank Aline Solari for her help in the statistical analysis, and Elisabeth Sambrony and Odile Marcuzzi for their technical assistance. This work was supported by a "Yad Hanadiv" research grant to Y.Z.

\section{REFERENCES}

Bommelaer, M. C., Billard, R., and Breton, B. (1981). Changes in plasma gonadotropin after ovariectomy and estradiol supplementation at different stages at the end of the reproductive cycle in the rainbow trout (Salmo gairdneri R.). Reprod. Nutr. Dev, 21, 989-997.

Breton, B., Billard, R., Jalabert, B., and Kann, G. (1972). Dosage radioimmunologique des gonadotropines plasmatiques chez Carassius auratus, au cours du nycthemere et pendant l'ovulation. Gen. Comp. Endocrinol. 18, 463-468.

Breton, B., Fostier, A., Zohar, Y., Le Bail, P. Y., and Billard, R. (1983). Gonadotropine glycoproteique maturante et oestradiol-17 $\beta$ pendant le cycle re- producteur chez la truite fario (Salmo trutta) femelle. Gen. Comp. Endocrinol. 49, 220-231.

Breton, B., Horoszewicz, L., Bieniarz, K., and Epler, P. (1980). Temperature and reproduction in tench: Effect of a rise in the annual temperature regimc on gonadotropin level, gametogenesis and spawning. II. The female. Reprod. Nutr. Dev. 20 , 1011-1024.

Bromage, N. R., Whitehead, C., and Breton, B. (1982). Relationships between serum levels of gonadotropin, oestradiol-17 $\beta$ and vitellogenin in the control of ovarian development in the rainbow trout. II. The effects of alterations in environmental photoperiod. Gen. Comp. Endocrinol. 47, $366-376$.

Bry, C. (1981). Temporal aspects of macroscopic changes in rainbow trout (Samo gairdneri) oocytes before ovulation and of ova fertility during the post-ovulation period: Effect of treatment with $17 \alpha$-hydroxy-20 $\beta$-dihydroprogesteronc. Aquaculture 24, 153-160.

Crim, L. W., Watts, E. G., and Evans, D. M. (1975). The plasma gonadotropin profilc during sexual maturation in a variety of salmonid fishes. Gen. Comp. Endocrinol. 27, 62-70.

De Vlaming, V. L., and Vodicnik, M. J. (1977). Diurnal variations in pituitary gonadotropin content and in gonadal response to exogenous gonadotropin and prolactin in Notemigonus crysoleucas. J. Fish. Biol. 10,371-383.

Egami, N. (1954). Effect of artificial photoperiodicity on time of oviposition in the fish, (Orysias latipes). Annot. Zool. Japan. 27, 57-62.

Fostier, A., and Jalabert, B. (1982). Physiological basis of practical means to induce ovulation in fish. In "Reproductive Physiology of Fish", (C. J. J. Richter and H. J. Th. Goos, eds.), pp. 164-173. Pudoc, Wageningen.

Fostier, A., and Jalabert, B. (1986). Steroidogenesis in rainbow trout (Salmo gairdneri) at various preovulatory stages: Changes in plasma hormone levels and in vivo and in vitro responses of the ovary to salmon gonadotropin. Fish Physiol. Biochem., in press.

Fostier, A., Breton, B., Jalabert, B., and Marcuzzi, O. (1981a). Evolution des niveaux plasmatiques de la gonadotropine glycoprotcique et de la $17 \alpha$-hydroxy-20ß-dihydroprogesterone au cours de la maturation et de l'ovulation chez la truite arc-enciel, (Salmo gairdneri). C. R. Acad. Sci. (Paris) Ser. HI. 293, 817-820.

Fostier, A., Jalabert, B., Campbell, C., Terqui, M., and Breton, B. (1981b). Cinetique de liberation in

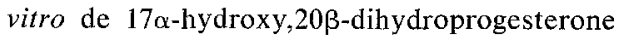
par des follicules de truite arc-en-ciel, (Salmo gairdneri). C. R. Acad. Sci. (Paris) Ser. III 292, 777-780.

Fostier, A., Weil, C., Terqui, M., Breton, B., and Ja- 
labert, B. (1978). Plasma estradiol-17ß and gonadotropin during ovulation in rainbow trout (Salmo gairdneri R.). Ann. Biol, Anim. Biochim. Biophys. 18, 929-936.

Harrington, R. W. (1963). Twenty-four hour rhythms of internal self fertilization and of oviposition by hermaphrodites of Rivulus marmoratus. Physiol. Zool. 36, 325-341.

Hontela, A., and Peter, R. E. (1978). Daily cycles in serum gonadotropin levels in the goldfish: Effects of photoperiod, temperature, and sexual condition. Canad. J. Zool. 56, 2430-2442.

Hubbs, C. (1976). The diel reproductive pattern and fecundity of Menidia audens. Copeia 1976, $386-388$.

Iwamatsu, T. (1978). Studies on oocyte maturation of the medaka, (Oryzias latipes). VI. The relationship between the circadian cycle of oocyte maturation and activity of the pituitary gland. J. Exp. Zool. 206, 355-364.

Jalabert, B. (1978). Production of fertilizable oocytes from follicles of rainbow trout (Salmo gairdneri) following in vitro maturation and ovulation. Ann. Biol. Anim. Biochim. Biophys. 18, 461-470.

Jalabert, B., Breton, B., and Bry, C. (1980). Evolution de la gonadotropine plasmatique $\mathrm{t}-\mathrm{GtH}$ apres synchronisation des ovulations par injection de $17 \alpha$-hydroxy-20 $\beta$-dihydroprogesterone chez la truite arc-en-ciel (Salmo gairdneri R.). C. $R$. Acad. Sci. (Paris) Ser. D. 290, 1431-1434.

Jalabert, B., Bry, C., Breton, B., and Campbell, C. (1976). Action de la 17 $\alpha$-hydroxy,20ß-dihydroprogesterone et de la progesterone sur la maturation et l'ovulation in vivo et sur le niveau d'hormone gonadotrope plasmatique $\mathrm{t}-\mathrm{GtH}$ chez la truite arcen-ciel (Salmo gairdneri). C. R. Acad. Sci. (Paris) Ser. D 283, 1205-1208.

Jalabert, B., Bry, C., Szollosi, D., and Fostier, A. (1973). Etude comparee de l'action des hormones hypophysaires et steroides sur la maturation in vitro des ovocytes de la truite et du carassin (poissons teleosteens). Ann. Biol. Anim. Biochim. Biophys. 13, 59-72.

Kagawa, H., Young, G., and Nagahama, Y. (1983). Changes in plasma steroid hormone levels during gonadal maturation in female goldfish, Carassius auratus. Bull. Japan. Soc. Sci. Fish. 49, 1783-1787.

Kuo, C. M., and Watanabe, W. O. (1978). Circadian responses of teleostean oocytes to gonadotropins and prostaglandins determined by cyclic AMP concentration. Ann. Biol. Anim. Biochim. Biophys. 18, 949-956.

Lamba, V. J., Goswami, S. V., and Sundararaj, B. I. (1983). Circannual and circadian variations in plasma levels of steroids (cortisol, estradiol-17 $\beta$, estrone, and testosterone) correlated with the an- nual gonadal cycle in the cattish, Heteropneustes fossilis (Bloch). Gen. Comp. Endocrinol. 50 , $205-225$.

MacGregor, R., Greeley, M. S., Reddington-Dodson, M. C., and Pagel, P. (1985). Effects of temperature and photoperiod on the seasonal and diel fluctuations of gonadal steroids in teleost fishes. In "Current Trends in Comparative Endocrinology" (B. Lofts and W. N. Holmes, eds.), pp. 691-693. Hong Kong Univ. Press, Hong Kong.

Marshall, J. A. (1967). Effect of artificial photoperiodicity on the time of spawning in Trichopsis vittatus and $T$. pumilus (Pisces, Belontidae). Anim. Behav. 15, 510-513.

Norcross, J. J., Richardson, S. L., Massmann, W. N., and Joseph, E. B. (1974). Development of young bluefish (Pomatomus saltatrix) and distribution of eggs and young in Virginian coastal waters. Trans. Amer. Fish. Soc. 3, 477-497.

Pan, J., Wang, R., Shen, R., Xu, G., Pao, X., and Xu, W. (1980). On the mode of pituitary gonadotropin releasing in carps. J. Fish China 4, 121-127.

Peter, R. E., Paulencu, C. R., and Breton, B. (1982). Temporal responsiveness of the ovary of goldfish to gonadotropin. J. Interdiscip. Cucle Res. 13 , $229-239$.

Peter, R. E., Sokolowska, M., Truscott, B., Walsh, I., and Idler, D. R. (1984). Secretion of progestogens during induced ovulation in goldfish. Canad. $J$. Zool. 62, 1946-1949.

Robinson, E. J., and Rugh, R. (1943). The reproductive processes of the fish Orizias latipes. Biol. Bull. 84, 115-125.

Scott, A. P., and Baynes, S. M. (1982). Plasma levels of sex steroids in relation to ovulation and spermiation in rainbow trout, (Salmo gairdneri). In "Reproductive Physinlogy of Fish" (C. I. I Richter and H. J. Th. Goos, eds.), pp. 103-106. Pudoc, Wageringen.

Scott, A. P., and Sumpter, J. P. (1983). A comparison of the female reproductive cycles of autumnspawning and winter-spawning strains of rainbow trout (Salmo gairdnert Richardson). Gen. Comp. Endocrinol. 52, 79-85.

Scott, A. P., Mackenzie, D. S., and Stacey, N. E. (1984). Endocrine changes during natural spawning in the white sucker, Catostomus commersoni. II. Steroid hormones. Gen. Comp. Endocrinol. 56, 349-359.

Scott, A. P., Sheldrick, E. L., and Flint, A. P. F. (1982). Measurement of $17 \alpha-20 \beta$-dihydroxy-4 pregnen-3-one in plasma of trout ( 5 almo gairdneri R.): Seasonal changes and response to salmon pituitary extract. Gen. Comp. Endocrinol. 46, $444-451$.

Scott, A. P., Sumpter, J. P., and Hardiman, P. A. (1983). Hormone changes during ovulation in the 
rainbow trout (Salmo gairdneri Richardson). Gen. Comp. Endocrinol, 49, 128-134.

Sokolowska, M., Peter, R. E., Nahorniak, C. S., Pan, C. H., Chang, J. P., Crim, L. W., and Weil, C. (1984). Induction of ovulation in goldfish, Carassius auratus, by pimozide and analogues of LH-RH. Aquaculture 36, 71-83.

Stacey, N. E., Cook, A. F., and Peter, R. E. (1979a). Ovulatory surge of gonadotropin in the goldfish (Carassius auratus). Gen. Comp. Endocrinol. 37, 246-249.

Stacey, N. E., Cook, A. F., and Peter, R. E. (1979b). Spontaneous and gonadotropin induced ovulation in the goldfish, (Carassius auratus L.): Effects of external factors. J. Fish. Biol. 15, 349-361.

Stacey, N. E., Mackenzie, D. S., Marchant, T. A., Kyle, A. L., and Peter, R. E. (1984). Endocrine changes during natural spawning in the white sucker, Catostomus commersoni. I. Gonadotropin, growth hormone, and thyroid hormones. Gen. Comp. Endocrinol. 56, 333-348.

Stacey, N. E., Peter, R. E., Cook, A. F., Truscott, B., Walsh, J. M., and Idler, D. R. (1983). Changes in plasma concentrations of gonadotropin, $17 \beta$-estradiol, testosterone, and $17 \alpha$-hydroxy-20 $\beta$-dihydroprogesterone during spontaneous and brain lesion induced ovulation in goldfish. Canad. J. Zool. 61, 2646-2654.

Stepkina, M. V. (1973). Some biological characteristics of Pagrus ehrenbergii Val. J. Ichryol. 13, 641-649.

Whitehead, C., Bromage, N. R., and Breton, B. (1983). Changes in serum levels of gonadotropin, oestradiol $17 \beta$ and vitellogenin during the first and subsequent reproductive cycle of female rainbow trout. Aquaculture 4, 317-326.

Wright, R. S., and Hunt, S. M. V. (1982). A radioimmunoassay for $17 \alpha-20 \beta$-dihydroxy-4-pregnen-3one: Its use in measuring changes in serum levels at ovulation in Atlantic salmon (Salmo salar), coho salmon (Oncorhynchus kisutch), and rainbow trout (Salmo gairdneri). Gen. Comp. Endocrinol. 47, 475-482.

Yamauchi, K., Kagawa, H., Ban, M., Kasahara, N., and Nagahama, Y. (1984). Changes in plasma estradiol-17 $\beta$ and $17 \alpha, 20 \beta$-dihydroxy-4-pregnen-3one levels during final oocyte maturation of the masu salmon Oncorhynchus masou. Bull. Japan. Soc. Sci. Fish. 50, 2137.

Young, G., Crim, L. W., Kagawa, H., Kambegawa, A., and Nagahama, Y. (1983). Plasma 17 $\alpha, 20 \beta$-dihydroxy-4-pregnen-3-one levels during sexual maturation of amago salmon (Oncorhynchus rhodurus): Correlation with plasma gonadotropin and in vitro production by ovarian follicles. Gen. Comp. Endocrinol. 51, 96-105.

Zohar, Y. (1982). "The Evolution of the Pulsatility and Circadian Rhythms of Gonadotropin Secretion in the Female Rainbow Trout throughout the Sexual Cycle and in Relation to the Steroidogenic Activity of the Ovary." Ph.D. (Doctorat d'Etat es Sciences Naturelles), Faculty of Science, University of Pierre and Marie Curie, Paris VI.

Zohar, Y., and Gordin, H. (1979). Spawning kinetics in the gilthead seabream, Sparus aurata L. after low doses of human chorionic gonadotropin. J. Fish. Biol. 15, 665-670.

Zohar, Y., Breton, B., and Fostier, A. (1982). Gonadotropic function during the reproductive cycle of the fenale rainbow trout, Salmo guirdneri, in relation to ovarian steroid secretion: In vivo and in vitro studies. In "Reproductive Physiology of Fish"' (C. J. J. Richter and II. J. Th. Goos, eds.), pp. 14-18. Pudoc, Wageningen.

Zohar, Y., Breton, B., and Fostier, A. (1986). Shortterm profiles of plasma gonadotropin and estradiol- $17 \beta$ levels in the female rainbow trout, from early ovarian recrudescence and throughout vitellogenesis. Gen. Comp. Endocrinol. 64, $172-188$. 